\title{
Chemical Characterization and Application of the Essential Oils from Chenopodium ambrosioides and Philodendron bipinnatifidum in the Control of Diabrotica speciosa (Coleoptera: Chrysomelidae)
}

\author{
Juliana de Andrade Santiago ${ }^{1}$, Maria das Graças Cardoso ${ }^{1 *}$, \\ Ana Cristina da Silva Figueiredo², Jair Campos de Moraes $^{3}$, \\ Franscinely Aparecida de Assis ${ }^{3}$, Maria Luisa Teixeira', Wilder Douglas Santiago1, \\ Thaís Aparecida Sales ${ }^{1}$, Karen Caroline Camargo ${ }^{1}$, David Lee Nelson" \\ ${ }^{1}$ Department of Chemistry, Federal University of Lavras, Lavras, Brazil \\ ${ }^{2}$ Centro de Biotecnologia Vegetal, IBB, DBV, Faculdade de Ciências de Lisboa, Universidade de Lisboa, \\ Lisboa, Portugal \\ ${ }^{3}$ Department of Entomology, Federal University of Lavras, Lavras, Brazil \\ ${ }^{4}$ Federal University of Vales de Jequitinhonha e Mucuri, Diamantina, Brazil \\ Email: * mcardoso@dqi.ufla.br
}

Received 6 October 2014; revised 2 November 2014; accepted 8 December 2014

Copyright (C) 2014 by authors and Scientific Research Publishing Inc.

This work is licensed under the Creative Commons Attribution International License (CC BY). http://creativecommons.org/licenses/by/4.0/

(c) (i) Open Access

\begin{abstract}
The compositions of essential oils from Chenopodium ambrosioides L. and Philodendron bipinnatifidum Schott were determined, and their potential effects on the nutrition and mortality of Diabrotica speciosa were studied. The extraction of the oils was performed by hydrodistillation ( $2 \mathrm{~h}$ ) using a modified Clevenger apparatus and the oils were subsequently subjected to analysis by gas chromatography/flame ionization detector (CG/FID) and gas chromatography/mass spectrometry (GC-MS). A completely randomized design with five treatments and four replications was adopted. The bean plants were sprayed with solutions of the oils dissolved in aqueous Tween 80 solutions at concentrations of 0 (water + Tween 80 ), $0.5 \%, 1.0 \%, 1.5 \%$ and $2.0 \%$ and then furnished to the insects with no choice available. Seven days after the application, the percentage of leaves with injury, degree of defoliation, the preference index for consumption and the percent of mortality of insects were evaluated. Neither of the essential oils caused a reduction in foliar injury, but antifeeding activity was observed, causing reduced feeding and increasing the mortality of adult $D$.
\end{abstract}

${ }^{*}$ Corresponding author.

How to cite this paper: Santiago, J.A., et al. (2014) Chemical Characterization and Application of the Essential Oils from Chenopodium ambrosioides and Philodendron bipinnatifidum in the Control of Diabrotica speciosa (Coleoptera: Chrysomelidae). American Journal of Plant Sciences, 5, 3994-4002. http://dx.doi.org/10.4236/ajps.2014.526417 


\section{speciosa insects.}

\section{Keywords}

Dietary Behavior, Insecticidal Activity, Bean, Natural Products

\section{Introduction}

Diabrotica speciosa (Germar, 1824) (Coleoptera: Chrysomelidae) is a major pest of dry beans and some vegetable crops. It has spread throughout all the Brazilian states and other countries of South America [1]. In Brazil, in addition to beans [2], this pest has been recorded to cause damage to corn [3], soy [4], and potatoes [5], among others.

The control of this insect pest is accomplished primarily by spraying synthetic insecticides based on active ingredients such as lufenuron [6], $\beta$-cyfluthrin and methamidophos [7]. But, the development of insect resistance to this products, the high operational cost and environmental impacts have created the need for developing alternative approaches to control many insects pest, and in this sense the essential oils are an alternative to control many insects [8].

Essential oils are complex mixtures of volatile compounds of different chemical origins [9]. They possess important biological activities, especially for the agrochemical industry that seeks to develop natural insecticides. In this context, these compounds are an alternative for the control of insect pests [10]. They may act as repellants [11], reduce feeding activity [12] or cause death [13].

Chenopodium ambrosioides L., popularly known as Santa Maria herb, is a native species of tropical South America, principally Mexico. Currently, it is distributed throughout the tropical, subtropical and temperate regions. The essential oil from $C$. ambrosioides contains substances with fungicide, acaricide, bactericide, nematicide, insecticide, molluscicide and allelopathic properties [14].

The Philodendron bippinatifidum Schott (Araceae) species is widely distributed throughout Brazil. It has root struts by which it rests on a support and roots for absorption of water and minerals [15]. The roots of different species of Philodendron are used in traditional medicine in the Amazon region, as well as for bathing and fumigation [16].

The study of plants with insecticidal activity to provide data that serve to aid in the development of insecticides of plant origin that have interesting biological potentials is important. The importance of studying the $C$. ambrosioides L. Schott and P. bipinnatifidum species should be emphasized. The present study involved the characterization of the essential oils from these two species and the evaluation of their effects on foliar injury, feeding activity and mortality of $D$. speciosa in the common bean plant.

\section{Material and Methods}

\subsection{Extraction of Essential Oils}

The leaves of the C. ambrosioides plant were collected in the Medicinal Plants Garden of the Federal University of Lavras (UFLA), Minas Gerais (MG), Brazil. The roots of the P. bipinnatifidum species were collected on a farm in the municipality of Pains, MG, Brazil. The collection site for C. ambrosioides has the following coordinates: $21^{\circ} 13^{\prime} 49.0476^{\prime \prime} \mathrm{S}, 44^{\circ} 58^{\prime} 27.4764^{\prime \prime} \mathrm{W}$ and $933 \mathrm{~m}$ altitude. The location for the collection of P. bipinnatifidum was $20^{\circ} 22^{\prime} 13^{\prime \prime} \mathrm{S}, 45^{\circ} 65^{\prime} 71^{\prime \prime} \mathrm{W}$ and $923 \mathrm{~m}$ altitude. The ratification of the taxonomic species was performed in the ESAL Herbarium (Herbarium, Department of Biology, UFLA). A voucher specimen of each species was incorporated into the collection of the Herbarium under registration number ESAL 26769 for C. ambrosioides and registration number ESAL 27111 for P. bipinnatifidum.

The extraction of the essential oils was performed at the Laboratory of Organic Chemistry-Essential Oils, Department of Chemistry, UFLA. The material was subjected to hydrodistillation for two hours using a modified Clevenger apparatus coupled to a 5-liter round bottom flask. The hidrolact was collected and centrifuged in a horizontal crosshead centrifuge at $1100 \mathrm{~g}$ for $5 \mathrm{~min}$. The essential oil was removed with the aid of a Pasteur pipette, packed in a glass flask that was wrapped with aluminum foil and stored under refrigeration [17]. 


\subsection{Identification of Constituents of the Essential Oils}

The GC-MS analyses were performed on a Perkin Elmer Autosystem XL gas chromatograph equipped with a fused silica column (30 m $\times 0.25 \mathrm{~mm}$ ID, DB-1 film thickness, $0.25 \mathrm{mM}$; J \& W Scientific Inc.) coupled to a Perkin Elmer TurboMass mass spectrometer (software version 4.1). The oven temperature was programmed from $45^{\circ} \mathrm{C}$ to $175^{\circ} \mathrm{C}$ at a rate of $3^{\circ} \mathrm{C} / \mathrm{min}$, and, subsequently, $15^{\circ} \mathrm{C} / \mathrm{min}$ to $300^{\circ} \mathrm{C}$, where the temperature was held constant for $10 \mathrm{~min}$. The transfer line temperature was $280^{\circ} \mathrm{C}$, the temperature of the ionization chamber was $220^{\circ} \mathrm{C}$, and the carrier gas was helium at a linear velocity of $30 \mathrm{~cm} / \mathrm{s}$. The split ratio was 1:40.

The identities of the compounds were determined by comparison of their retention indices with those of the C9-C21 n-alkanes and by comparing the mass spectra with those of standard commercial and reference compounds present in existing oils in the laboratory, as well as by comparison with a mass spectral library developed at the laboratory of the Centro de Biotecnologia Vegetal, Faculdade de Ciências, Universidade de Lisboa [18].

\subsection{Quantification of Constituents of Essential Oils}

The essential oils were analyzed by gas-liquid chromatography on a Perkin Elmer 8700 gas chromatograph equipped with two flame ionization detectors, a system for processing data and an autoinjector. Two columns of different polarity were installed with the following characteristics: DB-1 methyl silicone immobilized phase in a fused silica column ( $30 \mathrm{~m} \times 0.25 \mathrm{~mm}$ ID, film thickness $0.25 \mathrm{~mm}$; J \& W Scientific Inc.); DB-17HT phenylmethylsilicone stationary phase ( $30 \mathrm{~m} \times 0.25 \mathrm{~mm}$ ID; film thickness $0.25 \mathrm{~mm}$ ). The oven temperature was programmed from $45^{\circ} \mathrm{C}$ to $175^{\circ} \mathrm{C}$ at a rate of $3^{\circ} \mathrm{C} / \mathrm{min}$, and, subsequently, $15^{\circ} \mathrm{C} / \mathrm{min}$ to $300^{\circ} \mathrm{C}$, where the temperature was maintained for $10 \mathrm{~min}$. The temperature of the injector and detector ports was $290^{\circ} \mathrm{C}$ and $280^{\circ} \mathrm{C}$ respectively. The carrier gas was hydrogen, adjusted to a linear velocity of $30 \mathrm{~cm} / \mathrm{s}$. The split ratio was 1:50. The percentage composition of the oils was determined by integration of peak areas without using correction factors. The values given represent the average of two injections [18].

\subsection{Bioactivity of Essential Oils}

Bioassays with $D$. speciosa were conducted at the Laboratory of Plant Resistance to Insects, Department of Entomology, UFLA, according to the method described by Assis et al. [19], with modifications. The bean plants were grown in pots with a capacity of $3 \mathrm{~kg}$ using the C Horizon soil (Latossolo Vermelho Escuro) fertilized with $3 \mathrm{~g}$ of NPK fertilizer (8-28-16) per pot, equivalent to $450 \mathrm{~kg} \cdot \mathrm{ha}^{-1}$, as substrate. Four carioca beans seeds were planted per vessel. The pots were kept on benches inside the greenhouse. Thinning was performed 20 days after planting, leaving three plants per pot.

The collection of non-sexed $D$. speciosa adults was performed in a corn field with the aid of a plastic aspirator attached to a glass container. Subsequently, the beetles were taken to the laboratory, where they were kept for 24 $h$ in an acrylic cage $(30 \times 30 \times 80 \mathrm{~cm})$ and fed with bean plants grown in pots.

A completely randomized design (CRD) with five treatments and four replications was employed. The statistical program used was Sisvar. Data were subjected to analysis of variance, and the average was compared by the Scott Knott Test at 5\% probability [20]. The bean plants were sprayed with solutions of essential oils dissolved in aqueous Tween 80 at concentrations of $0.5 \%, 1.0 \%, 1.5 \%$ and $2.0 \%$ using a $10 \mathrm{~mL}$ plastic hand sprayer. A $2.0 \%$ solution of Tween was applied as the control treatment. The solutions were sprayed to the point that they ran down the leaves and stems of the plants.

The vessels were distributed randomly on benches inside the climate chamber (temperature equal to $30^{\circ} \mathrm{C}$ during the day and $25^{\circ} \mathrm{C}$ at night, relative humidity, $70 \% \pm 10 \%$ and $12 \mathrm{~h}$ of light) and covered with organza fabric supported on two iron rods fixed to the substrate of the vessel, forming a cage of approximately $20 \mathrm{~cm}$ diameter and $60 \mathrm{~cm}$ high. Ten adults per cage were released after treatment [19]. Seven days after the application of the essential oils, the percentage of leaves with injury and the degree of defoliation were evaluated using the AM-300 portable meter (ADC BioScientific Ltd, England). The percent of insect mortality was also determined. In addition, the preference index (PI) with respect to consumption was also calculated according the method of Goeden and Kogan [21] using the following formula: PI $=2 \mathrm{~A} / \mathrm{A}+\mathrm{M}$, where $\mathrm{A}=$ degree of defoliation (plants with application of essential oils), $\mathrm{M}=$ consumed leaf area (control plant), PI = 1 (neutral), PI $<1$ (phagodeterent), IP > 1 (phagostimulant). 


\section{Results and Discussion}

\subsection{Chemical Composition of the Essential Oils}

The chemical components of essential oil of C. ambrosioides L. and P. bipinnatifidum followed by their calculated retention index and reported retention index with their contents expressed in percentage are in Table 1 and Table 2, respectively.

The principal component found in the essential oil from C. ambrosioides was $\alpha$-terpinene (40.7\%), followed by $p$-cymene (21.8\%) and trans-ascaridol (12.5\%) (Figure 1). A predominance of monoterpene hydrocarbons (62.8\%) and oxygenated monoterpenes (13.2\%) was observed.

The data obtained in this study confirm those of Monzote et al. [22], who identified $\alpha$-terpinene, $p$-cymene and ascaridol as the principal constituents of the oil from C. ambrosioides, with variations in chemical composition from $17.0 \%$ to $20.7 \%$, from $20.2 \%$ to $21.1 \%$ and from $30.5 \%$ to $47.1 \%$, respectively. Moreover, Borges et al. [23] encountered terpinolene (69.9\%) and ascaridol (17.1\%) in the essential oil from this species collected in Brazil. However, $\alpha$-terpinene (51.3\%), $p$-cymene (23.4\%) and $p$-mentha-1,8-diene (15.3\%) were the principal compounds encountered in C. ambrosioides plants harvested in Cameroon (Africa). This difference can be explained by the different locations where the plants were collected, among other factors [24].

The essential oil from P. bipinnatifidum contained $\beta$-bisabolene (65.3\%), trans- $\alpha$-bergamotene (9.9\%) (Figure 2 ), being composed principally of the sesquiterpene hydrocarbon compounds (91.6\%) and monoterpene hydrocarbons (3.7\%) (Table 2). Although the literature reports on the yield and composition of the essential oil from the roots of $P$. bippinatifidum are still scarce, $\alpha$-pinene (13.3\%), $\beta$-pinene (15.8\%), limonene (15.5\%), spathulenol (14.2\%) and caryophyllene oxide (10.3\%) have been found in the essential oils of plants of the Philodendron genus [25]. This composition differs from the data presented in the present study. The discrepancy of this information is probably related to the fact that the species studied are distinct and have a resemblance only at the genus level.

Table 1. Composition of the essential oil from Chenopodium ambrosioides L.

\begin{tabular}{|c|c|c|}
\hline Compound & $\mathbf{R I}_{\text {cal }}$ & Percent Composition (\%) \\
\hline Benzaldehyde & 927 & $\mathrm{v}$ \\
\hline$\alpha$-Pinene & 930 & $\mathrm{v}$ \\
\hline n-Octanal & 973 & $\mathrm{v}$ \\
\hline$\beta$-Myrcene & 975 & $\mathrm{v}$ \\
\hline$\alpha$-Terpinene & 1002 & 40.73 \\
\hline$p$-Cymene & 1003 & 21.81 \\
\hline$\beta$-Phellandrene & 1005 & $\mathrm{v}$ \\
\hline Limonene & 1009 & 0.24 \\
\hline trans- $\beta$-Ocimene & 1027 & $\mathrm{v}$ \\
\hline$\gamma$-Terpinene & 1035 & $\mathrm{v}$ \\
\hline n-Octanol & 1045 & $\mathrm{v}$ \\
\hline Dimethyl styrene & 1059 & $\mathrm{v}$ \\
\hline n-Nonanal & 1073 & $\mathrm{v}$ \\
\hline cis-Piperitone Epoxide & 1211 & 0.34 \\
\hline trans-Piperitone Epoxide & 1258 & 0.35 \\
\hline trans-Ascaridol & - & 12.49 \\
\hline Total Identified & & $75.95 \%$ \\
\hline
\end{tabular}

$\mathrm{RI}_{\text {cal }}=$ Calculated retention index, $\mathrm{N}$. area = Normalization of the area, $\mathrm{v}=$ vestigial (less than $0.01 \%$ ). 
Table 2. Composition of the óleo essential from Philodendron bipinnatifidum Schott.

\begin{tabular}{|c|c|c|}
\hline Compound & $\mathbf{R I}_{\text {cal }}$ & Percent Composition (\%) \\
\hline$\alpha$-Pinene & 930 & 1.48 \\
\hline Canphene & 938 & 0.12 \\
\hline Sabinene & 958 & 0.17 \\
\hline$\beta$-Pinene & 963 & 0.18 \\
\hline$\beta$-Myrcene & 975 & 1.16 \\
\hline$\alpha$-Phellandrene & 995 & $\mathrm{v}$ \\
\hline$\alpha$-Terpinene & 1002 & $\mathrm{v}$ \\
\hline p-Cymene & 1003 & $\mathrm{v}$ \\
\hline$\beta$-Phellandrene & 1005 & $\mathrm{v}$ \\
\hline Limonene & 1009 & 0.57 \\
\hline cis- $\beta$-Ocimene & 1017 & $\mathrm{v}$ \\
\hline trans- $\beta$-Ocimene & 1027 & $\mathrm{v}$ \\
\hline$\gamma$-Terpinene & 1035 & $\mathrm{v}$ \\
\hline$\alpha$-Cubebene & 1345 & 0.20 \\
\hline Cyclosativene & 1363 & 0.16 \\
\hline$\alpha$-Ylangene & 1371 & 0.03 \\
\hline$\alpha$-Copaene & 1375 & 3.33 \\
\hline 7-epi- $\alpha$-Cedrene & 1396 & 0.23 \\
\hline$\alpha$-Cedrene & 1400 & 0.12 \\
\hline$\beta$-Caryophylene & 1414 & 0.95 \\
\hline trans- $\alpha$-Bergamotene & 1434 & 9.97 \\
\hline$\alpha$-Himachalene & 1441 & 0.16 \\
\hline$\alpha$-Humulene & 1447 & 0.20 \\
\hline trans- $\beta$-Farnesene & 1455 & 2.30 \\
\hline$\beta$-Santalene & - & 1.25 \\
\hline trans-Cadina-1(6),4-diene & 1469 & 0.27 \\
\hline$\alpha$-Curcumene & 1475 & 1.99 \\
\hline$\beta$-Selinene & 1476 & 0.73 \\
\hline cis- $\beta$-Guaiene & 1478 & 0.05 \\
\hline Valencene & 1484 & 0.07 \\
\hline$\gamma$-Muurolene & 1493 & 0.54 \\
\hline$\alpha$-Muurolene & 1494 & 0.45 \\
\hline$\beta$-Bisabolene & 1500 & 65.26 \\
\hline trans-Calamenene & 1505 & $\mathrm{v}$ \\
\hline$\delta$-Cadinene & 1505 & 2.83 \\
\hline$\alpha$-Calacorene & 1525 & 0.28 \\
\hline Germacrene B & 1533 & 0.12 \\
\hline trans- $\alpha$-Bisabolene & 1536 & 0.14 \\
\hline trans-Nerolidol & 1549 & $\mathrm{v}$ \\
\hline$\alpha$-Caryophyllene oxide & 1561 & 0.05 \\
\hline 1-epi-Cubenol & 1600 & 0.17 \\
\hline epi- $\alpha$-Cadinol & 1616 & $\mathrm{v}$ \\
\hline$\beta$-Bisabolol & - & 0.19 \\
\hline$\alpha$-Bisabolol & 1656 & 0.03 \\
\hline epi- $\alpha$-Bisabolol & 1658 & 0.06 \\
\hline Total Identified & & $96.51 \%$ \\
\hline
\end{tabular}

$\mathrm{RI}_{\text {cal. }}=$ Calculated retention index, $\mathrm{N}$. area $=$ Normalization of the area, $\mathrm{v}=$ vestigial (less than $0.01 \%$ ). 


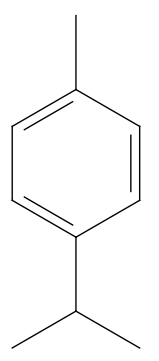

(a)

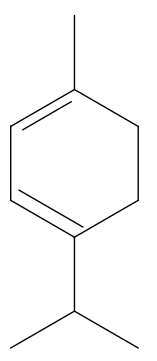

(b)

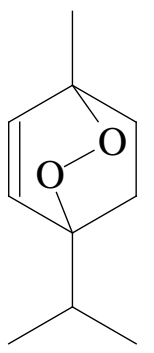

(c)

Figure 1. Chemical structures of the major components of the essential oil from C. ambrosioides L.: (a) p-cimene; (b) $\alpha$-terpinene; (c) trans-ascaridol.

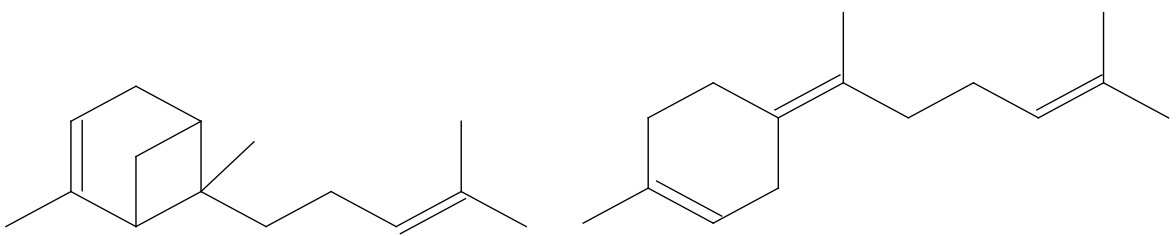

(a)

(b)

Figure 2. Chemical structures of the major components of the essential oil P. bipinnatifidum Schott: (a) trans- $\alpha$-bergamotene; (b) $\beta$-bisabolene.

\subsection{Activity of Essential Oils against Diabrotica speciosa}

It appears from the data presented in Table 3 that the use of the essential oils didn't contribute to a reduction in the number and degree of injuries in bean leaves caused by the chrysomelid because there was no significant difference between the treatments.

With regard to the leaf area consumed, an influence on the feeding behavior of the insect pest was observed for both the essential oils (Table 4). There was a decrease in the consumption of the leaves proportional to the increase in the concentrations of the essential oils.

With respect to the preference index for consumption, antifeedant activity (PI < 1) was observed for the essential oils at all the concentrations tested, i.e., they inhibited feeding by the defoliator beetle (Table 5).

It is known that the eating behavior of insects depends on the integration of the central nervous system with the chemoreceptors located on the shanks, the mouth parts and the oral cavity and insecticides found in plants can act upon the chemoreceptors by stimulating deterrent cells or blocking phagostimulating cells to inhibit feeding [26]. The results are similar to those found by Seffrin et al. [27] regarding the use of natural products that exert antifeedant activity against $D$. speciosa on the common bean, although the plants studied are different from those of the present study.

The chromatographic analysis allowed the identification of terpenes in essential oils. According to Viegas Júnior [28], the ecological importance of these compounds as pesticides plant is well elucidated, as several monoterpenes have been isolated and proved its toxicity against the different insects, ensuring a mortality ranging from $40 \%$ to $100 \%$. In addition, other classes of terpenes have been researched for a better understanding of their suppressive activities of feeding and repellency.

It is important to note that the efficiency of extracts or essential oils can be variable, depending on the plant species used and the species of insect pest to be controlled. Although the present study involved another kind of coleoptera, the mortality observed can be compared with that observed for the maize weevil Sitophilus zeamais by Mots, 1855; Coleoptera; Curculionidae) using powders of fruits and the whole C. ambrosioides. It had a highly toxic effect on the beetle [29].

Moreover, the reduction in the survival of $D$. speciosa was proportional to the concentrations of the essential oils. There was a significant difference between treatments with regard to the percentage of insect mortality, proving that some insecticidal action of the essential oils existed (Table 6). The insecticidal activity of the essential oils against insects can be attributed to the principal chemical constituents. However, the occurrence of synergism with the minor components may also encourage this activity. 
Table 3. Percentage of leaf injuries caused by Diabrotica speciosa in bean plants treated with different concentrations of the essential oils studied.

\begin{tabular}{|c|c|c|c|c|c|}
\hline \multicolumn{6}{|c|}{ Concentration (\%) } \\
\hline Species & 0.0 & 0.5 & 1.0 & 1.5 & 2.0 \\
\hline C. ambrosioides L. & $55.17 \pm 13.48 a$ & $49.72 \pm 10.18 a$ & $45.58 \pm 10.20 \mathrm{a}$ & $44.87 \pm 5.75 a$ & $38.64 \pm 6.15 a$ \\
\hline P. bipinatifidum & $58.20 \pm 13.19 a$ & $62.53 \pm 9.53 a$ & $86.46 \pm 17.80 a$ & $86.83 \pm 11.40 a$ & $72.30 \pm 14.65 a$ \\
\hline
\end{tabular}

Means followed by the same letter in the same line do not differ at a 5\% significance level by the Scott Knott Test.

Table 4. Leaf area $\left(\mathrm{cm}^{2}\right)$ consumed by Diabrotica speciosa on bean plants treated with different concentrations of the essential oils studied.

\begin{tabular}{|c|c|c|c|c|c|}
\hline \multicolumn{6}{|c|}{ Concentration (\%) } \\
\hline Species & 0.0 & 0.5 & 1.0 & 1.5 & 2.0 \\
\hline C. ambrosioides L. & $214.48 \pm 25.52 \mathrm{a}$ & $172.70 \pm 16.64 \mathrm{ab}$ & $162.04 \pm 53.17 \mathrm{ab}$ & $138.12 \pm 19.28 b$ & $120.75 \pm 31.48 b$ \\
\hline P. bippinatifidum & $532.78 \pm 32.49 a$ & $298.39 \pm 38.75 b$ & $197.87 \pm 25.76$ bc & $196.77 \pm 39.21$ bc & $137.93 \pm 26.71 c$ \\
\hline
\end{tabular}

Means followed by the same letter in the same line do not differ at a 5\% significance level by the Scott Knott Test.

Table 5. Preference index for feeding by Diabrotica speciosa on bean plants treated with different concentrations of the essential oils studied.

\begin{tabular}{ccc}
\hline & Preference index & \\
\hline Concentrations (\%) & C. ambrosioides & P. bipinnatifidum \\
Control & 1.00 & 1.00 \\
0.5 & 0.55 & 0.64 \\
1.0 & 0.58 & 0.73 \\
1.5 & 0.61 & 0.73 \\
2.0 & 0.64 & 0.80 \\
\hline
\end{tabular}

PI = 1(neutral); PI < 1 (phagodeterrent); PI > 1 (phagostimulant).

Table 6. Percent mortality of Diabrotica speciosa on bean plants treated with different concentrations of the essential oils studied.

\begin{tabular}{|c|c|c|c|c|c|}
\hline \multicolumn{6}{|c|}{ Concentration (\%) } \\
\hline Species & 0.0 & 0.5 & 1.0 & 1.5 & 2. 0 \\
\hline C. ambrosioides L. & $0.00 \pm 0.00 \mathrm{~b}$ & $5.00 \pm 5.77 b$ & $15.00 \pm 5.77 \mathrm{ab}$ & $23.75 \pm 9.46 a$ & $25.00 \pm 19.14 a$ \\
\hline P. bippinatifidum & $0.00 \pm 0.00 \mathrm{~b}$ & $2.50 \pm 5.00 \mathrm{~b}$ & $12.00 \pm 12.58 \mathrm{ab}$ & $15.00 \pm 12.91 a$ & $22.00 \pm 18.93 a$ \\
\hline
\end{tabular}

Means followed by the same letter in the same line do not differ at a 5\% significance level by the Scott Knott Test.

Thus, the use of the essential oils from the leaves of $C$. ambrosioides and roots of the P. bipinnatifidum species can be a viable alternative for the control of $D$. speciosa in the common bean. However, field trials are needed to prove the efficacy of such oils in controlling this chrysomelid under natural conditions.

\section{Conclusion}

The essential oil from C. ambrosioides L. contains $\alpha$-terpinene (40.73\%), p-cymene (21.81\%) and trans-ascaridol (12.48\%) as the principal compounds. The essential oil from P. bipinnatifidum Schott contains $\beta$-bisabolene (65.26\%) and trans- $\alpha$-bergamotene (9.97\%) as its major constituents. The application of the essential oils from 
C. ambrosioides and P. bipinnatifidum affected the behavior of D. speciosa, reducing the feeding activity and causing the death of the insect pest.

\section{Acknowledgements}

The authors thank the Conselho Nacional de Desenvolvimento Científico e Tecnológico (CNPq), the Coordenação de Aperfeiçoamento de Pessoal de Nível Superior (CAPES), the Fundação de Amparo à Pesquisa do Estado de Minas Gerais (FAPEMIG) for financial support and scholarships. The authors also thank PestOE/EQB/LA0023/2011. DLN was the recipient of a PVNS fellowship from CAPES.

\section{References}

[1] Bercellini, N. and Malacalza, L. (1994) Plagas y predadores en soja en el noroeste de la provincia de Buenos Aires (Arg.). Turrialba, 44, 244-254.

[2] Oliveira, M.B. and Ramos, V.M. (2012) Simulação de dano de Diabrotica em feijoeiro (Phaseolus vulgaris) para estimativa de nível de ação. Revista Agrarian, 5, 181-186.

[3] Marques, G.B.C., Ávila, C.J. and Parra, J.R.P. (1999) Danos causados por larvas e adultos de Diabrotica speciosa (Coleoptera: Chrysomelidae) em milho. Pesquisa Agropecuária Brasileira, 34, 1983-1986. http://dx.doi.org/10.1590/S0100-204X1999001100002

[4] Ávila, C.J. and Parra, J.R.P. (2002) Desenvolvimento de Diabrotica speciosa (Germar) (Coleoptera: Chrysomelidae) em diferentes hospedeiros. Ciência Rural, 32, 739-743. http://dx.doi.org/10.1590/S0103-84782002000500001

[5] Lara, F.M., Scaranello, A.L., Baldin, E.L.L., Boiça Jr., A.L. and Lourenção, A.L. (2004) Resistência de genótipos de batata a larvas e adultos de Diabrotica speciosa. Horticultura Brasileira, 22, 761-765. http://dx.doi.org/10.1590/S0102-05362004000400019

[6] Ávila, C.J. and Nakano, O. (1999) Efeito do regulador de crescimento lufenuron na reprodução de Diabrotica speciosa (Germar) (Coleoptera: Chrysomelidae). Anais da Sociedade Entomológica do Brasil, 28, 293-299. http://dx.doi.org/10.1590/S0301-80591999000200012

[7] Macêdo, L.B., Silva, A.L. and Silveira, C.A. (1997) Controle químico da vaquinha (Diabrotica speciosa GERM., 1824) e da cigarrinha verde (Empoasca kraemeri ROSS \& MOORE, 1957) em feijoeiro. Pesquisa Agropecuária Tropical, 27, 79-84.

[8] Pérez, S.G., Ramos-López, M.A., Zavala-Sánchez, M.A. and Cárdenas-Ortega, N.C. (2010) Activity of Essential Oils as a Biorational Alternative to Control Coleopteran Insects in Stored Grains. Journal of Medicinal Plants Research, 4, 2827-2835.

[9] Simões, C.M.O., Schenkel, E.P., Gosmann, G., Mello, J.C.P., Mentz, L.A. and Petrovick, P.R. (2007) Farmacognosia: Da planta ao medicamento. $6^{\mathrm{a}}$ Edição, UFSC/UFRGS, Porto Alegre, 1102p.

[10] Marangoni, C., Moura, N.F. and Garcia, F.R.M. (2012) Utilização de óleos essenciais e extratos de plantas no controle de insetos. Revista de Ciências Ambientais, 6, 95-112.

[11] Cruz, C.S.A., Pereira, E.R.L., Silva, L.M.M., Medeiros, M.B. and Gomes, J.P. (2012) Repelência do Callosobruchus maculatus (Coleoptera: Bruchidae) sobre grãos de feijão caupi tratado com óleos vegetais. Revista Verde de Agroecologia e Desenvolvimento Sustentável, 7, 1-5.

[12] Castro, D.P., Cardoso, M.G., Moraes, J.C., Santos, N.M. and Baliza, D.P. (2006) Não preferência de Spodoptera frugiperda (Lepidoptera: Noctuidae) por óleos essenciais de Achillea millefolium L. e Thymus vulgaris L. Revista Brasileira de Plantas Medicinais, 8, 27-32.

[13] Soares, C.S.A., Costa, M.B., Soares, A.H.V., Bezerra, C.E.S. and Carvalho, L.M. (2011) Avaliação da atividade inseticida do óleo essencial de mentrasto (Ageratum conyzoides L.) sobre o pulgão Macrosiphum euphorbiae (Thomas, 1878), (Hemiptera: Aphididae) em roseira. Revista Verde de Agroecologia e Desenvolvimento Sustentável, 6, 21-24.

[14] Lorenzi, H. and Matos, F.J.A. (2002) Plantas medicinais do Brasil: Nativas e exóticas. Instituto Plantarum, Nova Odessa, $512 \mathrm{p}$.

[15] Vianna, W.O., Soares, M.K.M. and Appezzato-Da-Glória, B. (2001) Anatomia da raiz escora de Philodendron bipinnatifidum Schott (Araceae). Acta Botanica Brasilica, 15, 313-320. http://dx.doi.org/10.1590/S0102-33062001000300003

[16] Castellar, A., Oliveira, D.R., Leitão, S.G., Bizzo, H.R., Soares, M.L.C., Kinupp, V.F. and Veiga Jr., V.F. (2013) Essential Oil from Philodendron fragrantissimum, an Aromatic Araceae from Amazonia, Brazil. Journal of Essential Oil Research, 25, 194-197. http://dx.doi.org/10.1080/10412905.2012.751557

[17] Brasil (2010) Agência Nacional de Vigilância Sanitária. In: Farmacopeia Brasileira, Vol. 1, 5a Edição, Anvisa, 
Brasília, 198-199.

[18] Mendes, M.D., Lima, A.S., Trindade, H., Correia, A.I.D., Barroso, J.G., Pedro, L.G. and Figueiredo, A.C. (2012) ISSR Molecular Characterization and Leaf Volatiles Analysis of Pittosporum undulatum Vent. Naturalized in the Azores Archipelago (Portugal). Industrial Crops and Products, 33, 710-719. http://dx.doi.org/10.1016/j.indcrop.2011.01.010

[19] Assis, F.A., Moraes, J.C., Nascimento, A.M. and Francoso, J. (2011) Efeitos da terra diatomácea sobre Diabrotica speciosa (Germar, 1824) (Coleoptera: Chrysomelidae) em batata inglesa. Ciência e Agrotecnologia, 35, 482-486. http://dx.doi.org/10.1590/S1413-70542011000300007

[20] Ferreira, D.F. (2011) SISVAR: A Computer Statistical Analysis System. Ciência e Agrotecnologia, 35, $1039-1042$.

[21] Goeden, R.D. and Kogan, M. (1970) The Host-Plant Range of Lema trilineata daturaphila (Coleoptera: Chrysomelidae). Annals of the Entomological Society of America, 63, 1175-1180.

[22] Monzote, L., Nance, M.R., Garcia, M., Scull, R. and Setzer, W.N. (2011) Comparative Chemical, Cytotoxicity and Antileishmanial Properties of Essential Oils from Chenopodium ambrosioides. Natural Product Communications, 6, 281-286.

[23] Borges, A.R., Aires, J.R., Higino, T.M., Medeiros, M.D., Citó, A.M., Lopes, J.A. and Figueiredo, R.C. (2012) Trypanocidal and Cytotoxic Activities of Essential Oils from Medicinal Plants of Northeast of Brazil. Experimental Parasitology, 132, 123-128. http://dx.doi.org/10.1016/j.exppara.2012.06.003

[24] Chekem, M.S.G., Lunga, P.K., Tamokou, J.D., Kuiate, J.R., Tane, P., Vilarem, G. and Cerny, M. (2010) Antifungal Properties of Chenopodium ambrosioides Essential Oil against Candida Species. Pharmaceuticals, 3, $2900-2909$. http://dx.doi.org/10.3390/ph3092900

[25] Bezerra, M.Z.B., Andrade-Neto, M., Freitas, R.M., Feitosa, C.M. and de Andrade, I.M. (2002) The Root Oil of Philodendron imbe Schott (Araceae). Journal of Essential Oil Research, 14, 56-57. http://dx.doi.org/10.1080/10412905.2002.9699763

[26] Azevedo, A.I.B., Lira, A.S., Cunha, L.C., Almeida, F.A.C. and Almeida, R.P. (2010) Bioatividade do óleo de nim sobre Alphitobius diaperinus (Coleoptera: Tenebrionidae) em sementes de amendoim. Revista Brasileira de Engenharia Agrícola e Ambiental, 14, 309-313. http://dx.doi.org/10.1590/S1415-43662010000300011

[27] Seffrin, R.C.A.S., Costa, E.C., Longhi, S.J., Lopes, S.J. and Santos, V.J. (2008) Comportamento alimentar de adultos de Diabrotica speciosa na presença de extratos aquosos de Meliaceae. Ciência Rural, 38, 2115-2118. http://dx.doi.org/10.1590/S0103-84782008000800004

[28] Viegas Jr., C. (2003) Terpenos com atividade inseticida: Uma alternativa para o controle químico de insetos. Química Nova, 26, 390-400. http://dx.doi.org/10.1590/S0100-40422003000300017

[29] Tavares, M.A.G.C. and Vendramim, J.D. (2005) Bioatividade da erva-de-santa-maria, Chenopodium ambrosioides L., sobre Sitophilus zeamais Mots. (Coleoptera: Curculionidae). Neotropical Entomology, 34, 319-323. http://dx.doi.org/10.1590/S1519-566X2005000200021 
Scientific Research Publishing (SCIRP) is one of the largest Open Access journal publishers. It is currently publishing more than 200 open access, online, peer-reviewed journals covering a wide range of academic disciplines. SCIRP serves the worldwide academic communities and contributes to the progress and application of science with its publication.

Other selected journals from SCIRP are listed as below. Submit your manuscript to us via either submit@scirp.org or Online Submission Portal.
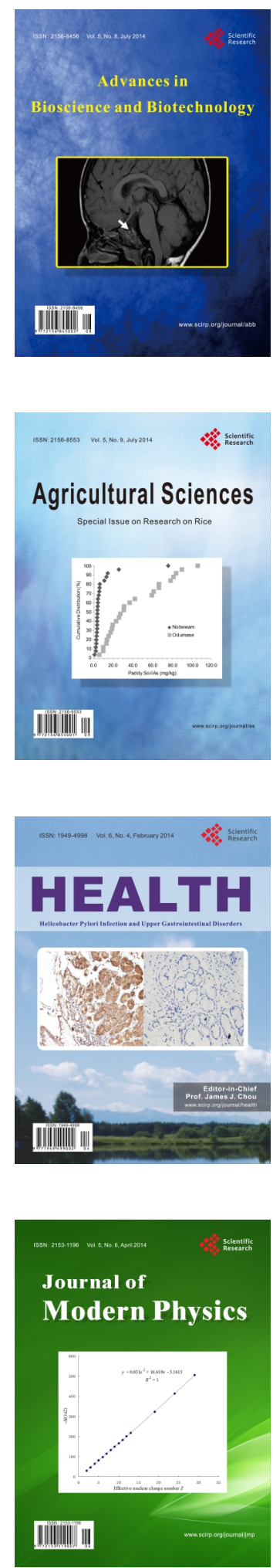
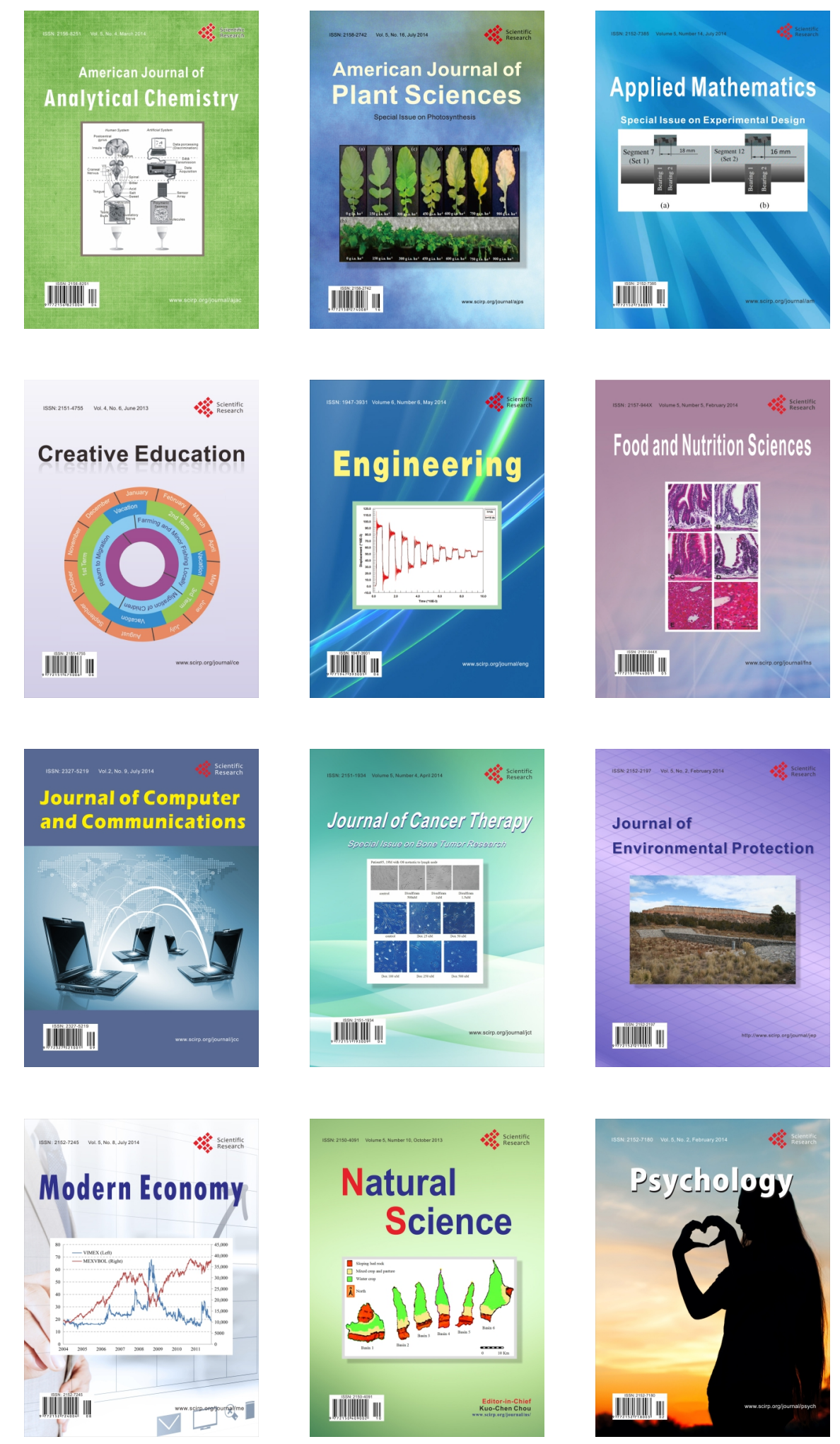